\title{
Analisis Faktor yang Berhubungan dengan Pemanfaatan Klinik VCT Pada LSL Remaja dengan Pendekatan Teori Health Belief Model (HBM) di Kota Kediri
}

\section{Analysis of Factors Associated with the Use of VCT Clinics in Adolescent MSM using the Theory of Health Belief Model (HBM) in Kediri}

\author{
Muhamad Solikul Hamdani*, Kun Ika Nurrahayu, Yeni L.N.A \\ *Program Studi Ilmu Keperawatan (S.1), Fakultas Ilmu Kesehatan, Universitas Kadiri \\ Kediri \\ JL, Selomangleng No. 1 Kediri, Telp.(0354)775074/771846 \\ Email: *solikulhamdani@gmail.com
}

\begin{abstract}
ABSTRAK
Program Voluntary Counseling and Testing (VCT) merupakan salah satu strategi kesehatan masyarakat yang di lakukan untuk menekan penyebaran HIV/AIDS. Tingginya kasus HIV/AIDS di Indonesia salah satunya dikarenakan minta seseorang yang berisiko untuk melakukan pemeriksaan VCT yang masih rendah. Teori Health Belief Model adalah model teoritis yang dapat digunakan untuk memandu promosi kesehatan dan program pencegahan penyakit. Tujuan penelitian ini yaitu untuk mengetahui faktor yang berhubungan dengan pemanfatan klinik VCT pada LSL remaja dengan pendekatan teori Health Belief Model (HBM) di Kota Kediri tahun 2020. Pwnwlitian ini termasuk penelitian analiotik korelasi dengan pendekatan Cross sectional. 83 sampel orang dipilih denagn porposive sampling. Variabel Independen variabel meliputi perceived susceptibility, perceived benefits, perceived barrier, perceived seriusnes, dan cues to action. Variabel dependen adalah pemanfaatan layanan VCT. Data di kumpulkan dengan kuesioner dan di analisis dengan sperman rank. Hasil menunjukan bahwa perceived susceptibility dengan pemanfaaatan layanan VCT $(p=0,255)$, perceived seriousness dengan pemanfaatan layanan VCT $(p=0,241)$, perceived benefits dengan pemanfaatan VCT $(p=0,064)$, perceived barrier dengan pemanfaatan layanan VCT $(p=0,026)$, Hubungan cues to action dengan pemanfaatan layanan VCT $(\mathrm{p}=0,169)$. Perceived susceptibility, perceived benefits, perceived seriusnes, dan cues to action tidak memiliki korelasi denagn pemanfaatan layana VCT, perceived barrier memiliki korelasi dengan pemanfaatan layanan VCT. Di saran kan bagi LM untuk sering memberikan informasi kepasa orang-orang beresiko tinggi HIV/AIDS.
\end{abstract}

Kata kunci : VCT, LSL, HIV, HBM 


\begin{abstract}
The Voluntary Counseling and Testing (VCT) program is one of the public health strategies implemented to reduce the spread of HIV / AIDS. The high number of HIV/AIDS cases in Indonesia is partly due to asking someone at risk to do a VCT examination, which is still low. The Health Belief Model theory is a theoretical model that can be used to guide health promotion and disease prevention programs. The purpose of this study was to determine the factors associated with the use of VCT clinics in adolescent MSM using the Health Belief Model (HBM) theoretical approach in Kota Kediri in 2020. This study was an analiotic correlation study with a cross sectional approach. 83 samples of people were selected by positive sampling. Independent variables include perceived susceptibility, perceived benefits, perceived barriers, perceived seriousness, and cues to action. The dependent variable is the use of VCT services. The data were collected by means of a questionnaire and analyzed with Sperman rank. The results showed that perceived susceptibility with the use of VCT services ( $p=0.255$ ), perceived seriousness with the use of VCT services $(p=0.241)$, perceived benefits with the use of VCT $(p=0.064)$, perceived barriers with the use of VCT services $(p=0.026)$, The relationship between cues to action and VCT service utilization $(p=0.169)$. Perceived susceptibility, perceived benefits, perceived seriousness, and cues to action do not have a correlation with the use of VCT services, perceived barriers have a correlation with the use of VCT services. $L M$ was advised to frequently provide information to people at high risk of HIV/AIDS.
\end{abstract}

Keywords : VCT, LSL, HIV, HBM

\title{
PENDAHULUAN
}

Lelaki Seks Lelaki (LSL) merupakan salah satu populasi yang beresiko tinggi terkena Infeksi Menular Seksual (IMS) dan Human Immunodeficiency Virus / Acquired Immune Deficiency Syndrome (HIV/AIDS), di karenakan melakukan seks beresiko (Carmelita et al., 2017).

HIV merupakan retrovirus yang menyerang sistem kekebalan tubuh atau sistem imun menusia. HIV menyerang sel-sel darah putih yang bertugas menangkal infeksi dan dapat menimbulkan kumpulan dari beberapa gejala penyakit atau yang kita kenal dengan AIDS (Purwoastuti, 2015).

Program Voluntary Counseling and Testing (VCT) merupakan salah satu strategi kesehatan masyarakat yang di lakukan untuk menekan penyebaran HIV/AIDS. Menurut Lestari (2016) dengan melakukan VCT, LSL dapat mengetahui status HIV, selain itu dalam proses konseling klien akan dapat mengetahu cara menjaga kesehatan seksualnya supaya terhindar dari penyakit IMS. Harapan di lakukan program VCT sebagai pencegahan penularan HIV sedini mungkin. Untuk 
mengetahui seseorang terinfeksi HIV atau tidak hanya dapat dilakukan melalui tes HIV.

Kejadian HIV pada tahun 2019 di laporan Kemenkes RI dari periode April sampai Juni tedapat kejadian kasus infeksi sejumlah 11.159 orang, persentase laporan tertinggi pada kelompok umur 25-49 tahun (71,1\%), di ikuti kelompok umur 20-24 tahun (14,4\%), dan kelompok umur > 50 tahun ( $9 \%)$, dengan rasio HIV antara laki-laki dan perempuan adalah 2:1 (Kemenkes RI, 2019).

Berdasarkan studi pendahuluan yang di lakukan di LSM Redline Kediri pada tanggal 18 November 2019 di dapatkan bahwa terdapat 105 LSL remaja periode juli sampai november 2019 dari jumlah tersebut di ketahui 44 orang LSL remaja telah melakukan VCT sementara 59\% dari 105 LSL remaja belum melakukan pemeriksaan VCT. Jadi berdasarka data yang di perolah dapat di simpulkan bahwa masih rendahnya LSL remaja yang melakukan VCT di Kota Kediri tahun 2019 (Redline, 2019).

Tingginya kasus HIV/AIDS di Indonesia salah satunya dikarenakan minta seseorang yang berisiko untuk melakukan pemeriksaan VCT yang masih rendah. Teori Health Belief Model adalah model teoritis yang dapat digunakan untuk memandu promosi kesehatan dan program pencegahan penyakit. HBM digunakan untuk menjelaskan dan memprediksi perubahan individu dalam perilaku kesehatan. HBM menjadi salah satu model yang paling banyak digunakan untuk memahami perilaku kesehatan (RHIHub, 2019).

\section{METODE PENELITIAN}

Penelitian ini termasuk penelitian analiotik korelasi dengan pendekatan Cross sectional. Variabel Independen variabel meliputi perceived susceptibility, perceived benefits, perceived barrier, perceived seriusnes, dan cues to action. Variabel dependen adalah pemanfaatan layanan VCT. Penelitian ini dilakukan di kota Kediri. Intrumen yang di gunakan koesioner . besar sampel 83 orang di pilih dengan purposive sampling .

\section{HASIL PENELITIAN}

\section{Karakteristik Demografi}

Data karakteristik demografi responden ini menjelaskan tentang karakteristik responden yang diteliti dengan jumlah 83 orang. Data yang dibahas meliputi usia, tempat tinggal, pernah mendengar tentang layanan VCT, jarak rumah dengan pelayanan kesehatan terdekat, pendidikan terakhir, serta pernah melakukan tes HIV atau tidak. 
Tabel 1 Distribusi frekuensi karakteristik demgrafi responden pemanfatan VCT leh LSL di Kediri

\begin{tabular}{|c|c|c|c|}
\hline No. & Karakteristik Responden & $\mathbf{F}$ & $\%$ \\
\hline \multirow[t]{7}{*}{1} & Usia & & \\
\hline & 16 tahun & 1 & 1,2 \\
\hline & 17 tahun & 5 & 6 \\
\hline & 18 tahun & 23 & 27,7 \\
\hline & 19 tahun & 25 & 30,1 \\
\hline & 20 tahun & 29 & 34,9 \\
\hline & Total & 83 & 100 \\
\hline \multirow[t]{5}{*}{2} & Status Pendidikan & & \\
\hline & SMP & 5 & 6 \\
\hline & SMA/SMK & 47 & 56,6 \\
\hline & Perguruan Tinggi & 31 & 37,3 \\
\hline & Total & 83 & 100 \\
\hline \multirow[t]{9}{*}{3} & Tempat Tinggal & & \\
\hline & Di kosan & 21 & 25,3 \\
\hline & Dengan orang tua & 61 & 73,5 \\
\hline & Rumah sendiri & 1 & 1,2 \\
\hline & Total & 83 & 100 \\
\hline & Pernah mendengar layanan & & \\
\hline & Ya & 52 & 62,7 \\
\hline & Tidak & 31 & 37,3 \\
\hline & Total & 83 & 100 \\
\hline \multirow[t]{5}{*}{5} & Jarak rumah ke layanan VCT & & \\
\hline & $<1 \mathrm{KM}$ & 41 & 49,4 \\
\hline & $1 \mathrm{KM}-3 \mathrm{KM}$ & 31 & 37,3 \\
\hline & $>3 \mathrm{KM}$ & 11 & 13,3 \\
\hline & Total & 83 & 100 \\
\hline \multirow[t]{4}{*}{6} & Pernah melakukan tes HIV & & \\
\hline & Ya & 38 & 45,8 \\
\hline & Tidak & 45 & 54,2 \\
\hline & Total & 83 & 100 \\
\hline
\end{tabular}


Hubungan perceived susceptibility dengan pemanfaaatan layanan VCT oleh LSL

Tabel 2 Distribusi Frekuensi Hubungan Perceived Susceptibility dengan Pemanfaaatan Layanan VCT oleh LSL di Kediri tahun 2020

\begin{tabular}{|c|c|c|c|}
\hline \multicolumn{4}{|c|}{ Spearman's rho } \\
\hline Variabel & $\begin{array}{c}\text { Correlation } \\
\text { Coefficient }\end{array}$ & Sig. (2-tailed) & Keterangan \\
\hline $\begin{array}{c}\text { Perceived } \\
\text { susceptibility dengan } \\
\text { Pemanfaatan VCT }\end{array}$ & 0,126 & 0,255 & Tidak ada hubungan \\
\hline
\end{tabular}

Berdasarkan tabel 2 diketahui bahwa hasil uji krelasi Hubungan perceived susceptibility dengan pemanfaaatan layanan VCT oleh LSL menunjukan bahwa Hasil uji statistik diperoleh $p=0,255(a \geq 0,05)$ dapat di simpulkan bahwa tidak terdapat hubungan yang signifikan antara perceived susceptibility dengan pemanfaaatan layanan VCT oleh LSL.

Hubungan perceived seriousness dengan pemanfaatan layanan VCT oleh LSL

Tabel 3 Distribusi Frekuensi Hubungan Perceived Seriousness dengan Pemanfaatan Layanan VCT oleh LSL tahun 2020

\begin{tabular}{|c|c|c|c|}
\hline \multicolumn{4}{|c|}{ Spearman's rho } \\
\hline Variabel & $\begin{array}{c}\text { Correlation } \\
\text { Coefficient }\end{array}$ & $\begin{array}{c}\text { Sig. (2- } \\
\text { tailed) }\end{array}$ & Keterangan \\
\hline $\begin{array}{c}\text { Perceived Seriousness } \\
\text { dengan Pemanfaatan } \\
\text { VCT }\end{array}$ & 0,130 & 0,241 & Tidak ada hubungan \\
\hline
\end{tabular}

Berdasarkan tabel 3 diketahui bahwa hasil uji krelasi Hubungan perceived seriousness dengan pemanfaaatan layanan VCT oleh LSL menunjukan bahwa Hasil uji statistik di peroleh $p=0,241(a \geq 0,05)$ dapat di simpulkan bahwa tidak terdapat hubungan yang signifikan antara perceived seriousness dengan pemanfaaatan layanan VCT oleh LSL.

Hubungan perceived benefits dengan pemanfaatan VCT oleh LSL

Tabel 4 Distribusi Frekuensi Ubungan Perceived Benefits dengan Pemanfaatan VCT oleh LSL tahun 2020

\begin{tabular}{|c|c|c|c|}
\hline \multicolumn{4}{|c|}{ Spearman's rho } \\
\hline Variabel & $\begin{array}{c}\text { Correlation } \\
\text { Coefficient }\end{array}$ & Sig. (2-tailed) & Keterangan \\
\hline $\begin{array}{c}\text { perceived benefits dengan } \\
\text { Pemanfaatan VCT }\end{array}$ & 0,205 & 0,064 & $\begin{array}{c}\text { Tidak ada } \\
\text { Hubungan }\end{array}$ \\
\hline
\end{tabular}


Berdasarkan tabel 4 diketahui bahwa hasil uji krelasi Hubungan perceived benefits dengan pemanfaaatan layanan VCT oleh LSL menunjukan bahwa Hasil uji statistik di peroleh $p=0,064$ ( $a \geq 0,05)$ dapat di simpulkan bahwa tidak terdapat hubungan yang signifikan antara perceived benefits dengan pemanfaaatan layanan VCT oleh LSL.

Hubungan perceived barrier dengan pemanfaatan layanan VCT oleh LSL Tabel 5 Distribusi Frekuensi Hubungan Perceived Barrier dengan Pemanfaatan Layanan VCT oleh LSL tahun 2020

\begin{tabular}{|c|c|c|c|}
\hline \multicolumn{4}{|c|}{ Spearman's rho } \\
\hline Variabel & $\begin{array}{c}\text { Correlation } \\
\text { Coefficient }\end{array}$ & Sig. (2-tailed) & Keterangan \\
\hline $\begin{array}{c}\text { Perceived barrier dengan } \\
\text { Pemanfaatan VCT }\end{array}$ & $-0,244$ & 0,026 & Ada Hubungan \\
\hline
\end{tabular}

Berdasarkan tabel 5 diketahui bahwa hasil uji krelasi Hubungan perceived barrier dengan pemanfaaatan layanan VCT oleh LSL menunjukan bahwa keeratan hubungan rendah $(r)$ sebesar $-0,244$ dan berpla negative artinya semakin tinggi perceived barrier maka semakin rendah untuk memanfaatkan VCT. Hasil uji statistik di peroleh $p=0,026$ ( $a \leq 0,05)$ dapat di simpulkan bahwa terdapat hubungan yang signifikan antara perceived barrier dengan pemanfaaatan layanan VCT oleh LSL.

\section{Hubungan cues to action dengan pemanfaatan layanan VCT oleh LSL}

Tabel 6 Distribusi Frekuensi Hubungan Cues To Action dengan Pemanfaatan Layanan VCT oleh LSL tahun 2020

\begin{tabular}{|c|c|c|c|}
\hline \multicolumn{4}{|c|}{ Spearman's rho } \\
\hline Variabel & $\begin{array}{c}\text { Correlation } \\
\text { Coefficient }\end{array}$ & Sig. (2-tailed) & Keterangan \\
\hline $\begin{array}{c}\text { Cues to action dengan } \\
\text { Pemanfaatan VCT }\end{array}$ & 0,152 & 0,169 & $\begin{array}{c}\text { Tidak Ada } \\
\text { Hubungan }\end{array}$ \\
\hline
\end{tabular}

Berdasarkan tabel 6 diketahui bahwa hasil uji krelasi Hubungan cues to action dengan pemanfaaatan layanan VCT oleh LSL menunjukan bahwa Hasil uji statistik di peroleh $p=0,169(a \geq 0,05)$ dapat di simpulkan bahwa tidak terdapat hubungan yang signifikan antara cues to action dengan pemanfaaatan layanan VCT oleh LSL.

\section{PEMBAHASAN}

\section{Hubungan perceived susceptibility dengan pemanfaaatan layanan VCT oleh LSL}

Penelitian ini menunjukan bahwa tidak terdapat hubungan antara perceived susceptibility dengan pemanfaatan VCT di wilayah Kediri tahun 2020. Responden yang memiliki persepsi kerentanan rendah mayoritas tidak melakukan pemeriksaan VCT. Semakin rendah perceived susceptibility, LSL cenderung untuk tidak 
memanfaatkan VCT dan sebaliknya semakin tinggi perceived susceptibility, LSL cenderung memanfaatkan VCT. Persepsi kerentanan yang lemah terhadap HIV/AIDS terjadi apabila tidak memiliki keyakinan bahwa dirinya berisiko menderita HIV/AIDS, tidak memiliki teman atau pasangan yang terinfeksi, serta tidak memiliki riwayat perilaku yang berisiko (Purwaningsih, Misutarno and Imamah, 2011).

Hasil penelitian ini sesua dengan penelitian yang dilakukan oleh Putu Krisna (2016) yang menyatakan bahwa tidak terdapat hubungan antara perepsi responden mengenai kerentanan terinfeksi HIV dan AIDS dengan perilaku tes HIV ( $p$-value 0.370). Penelitian ini tidak sejalan dengan penelitian yang dilakukan oleh Putra (2012) di mana dalam hasil penelitiannya disebutkan bahwa ada hubungan yang signifikan antara persepsi kerentanan terhadap HIV dengan penggunaan VCT.

Faktor yang mempengaruhi yaitu usia, tingkat pendidikan, dan lingkungan. Teori HBM menyatakan bahwa usia merupakan salah satu faktor pendukung untuk memperkuat faktor utama dari teori HBM (kerentanan, manfaat dan hambatan). Usia merupakan faktor modifkasi yang memiliki pengaruh pada kepercayaan untuk melakukan perilaku kesehatan dan bukan merupakan faktor utama pembentuk perilaku (Glanz and B. K Viswanath K, 2008). Dapat diartikan semakin cukup umur, semakin matang pula usia seseorang, semakin banyak pula pengalaman dan wawasan yang didapat yang akan mempengaruhi persepsi seseoorang.

Mayoritas responden memiliki tingkat pendidikan SMA. Fatmala (2016) Semakin tinggi pendidikan yang dimiliki responden maka akan semakin tinggi pula tingkat pengetahuan terkait VCT, informan yang memiliki tingkat pendidikan rendah juga mempunyai pengetahuan yang baik mengenai hal- hal yang berkaitan dengan VCT, HIV dan AIDS. Pemanfaatan VCT disebabkan karena adanya pengetahuan yang cukup tentang VCT, merasa beresiko dan adanya pengaruh dan ajakan dari luar (Wang, 2011). Pendidikan dapat memberikan pengaruh tidak langsung terhadap perilaku LSL melalui persepsi, LSL dengan pendidikan tinggi akan lebih memperhatikan masalah kesehatan. namun selain tingkat pendidikan faktor lingkungan juga memberikan pengaruh yang mendorong respoden untuk memanfaatkan layanan VCT, memalui ajakan teman dalam satu komunitas ataupun dari Pengawas Lapangan (PL). Dukungan dari petugas LSM dan petugas kesehatan dimana diselenggarakannya program VCT yang dilakukan oleh puskesmas.

Berdasarkan analisa data penulis menyimpulkan bahwa semakin rendah persepsi kerentanan seseorang terhadap HIV/AIDS, maka semakin kecil seseorang memanfaatkan layanan VCT untuk mengantisipasi penularan HIV/AIDS. Tantangan yang dirasakan masih besar dan berat karena kesadaran LSL masih rendah. Persepsi kerentanan LSL dapat ditingkatkan dengan memberikan pengetahuan secara terus menerus kepada kelompok LSL sehingga pada akhirnya dengan niat dan kesadaran yang tinggi mereka mau datang dan memanfaatkan layanan VCT secara sukarela. Dibutuhkan juga keseriusan pemerintah dalam menyikapi 
Jurnal Kesehatan Mahasiswa UNIK. Vol. 2, No. 1, Oktober 2020

P-ISSN: 2714-5409, E-ISSN: 2686-5300

kecenderungan meningkatnya HIV ini dimana fenomena ini ibarat gunung es yang semakin lama akan semakin susah diatasi.

\section{Hubungan perceived seriousness dengan pemanfaatan layanan VCT oleh LSL}

Penelitian ini menunjukan bahwa tidak terdapat hubungan antara perceived suriousness dengan pemeriksaan VCT di wilayah Kediri tahun 2020. Semakin tinggi perceived seriousness LSL cenderung untuk memanfaatkan VCT. Semakin rendah perceived seriousness LSL cenderung untuk tidak memanfaatkan VCT. Berdasarkan teori Becker (1974) dalam Notoadmodjo (2007), keseriusan yang dirasakan (perceived seriousness) adalah tindakan individu untuk mencari pengobatan dan pencegahan penyakit akan didorong pula oleh keseriusan penyakit tersebut terhadap individu atau masyarakat, sedangkan menurut pendapat Sarwono (2004) tentang keseriusan yaitu resiko kesulitan yang akan dirasakan individu terhadap suatu penyakit. Persepsi keseriusan yang dirasakan terhadap HIV/AIDS kemungkinan juga berbeda-beda pada setiap orang risiko tinggi, hal itu karena tiap orang yang beresiko tinggi memiliki pandangan yang subjektif terhadap keseriusan HIV/AIDS.

Hasil penelitian ini juga sejalan dengan penelitian yang dilakukan oleh Putu Krisna (2016) yang menyatakan bahwa tidak terdapat hubungan antara perepsi responden terhadap keparahan/keseriusan HIV dan AIDS dengan perilaku tes HIV. Penelitian ini tidak sejalan dengan penelitian Linda (2012) yang menyatakan ada hubungan yang signifikan antara persepsi keseriusan dengan perilaku pencegahan, bahwa semakin individu mempersepsikan bahwa penyakit yang dialami semakin memburuk, mereka akan merasakan hal tersebut sebagai ancaman dan mengambil tindakan preventif.

Faktor pengubah seperti tingkat pendidikan dipercayai mempunyai pengaruh tidak langsung terhadap perilaku dengan cara mempengaruhi persepsi individu seperti persepsi terhadap keseriusan. Individu dengan pendidikan tinggi, cenderung memiliki perhatian yang besar terhadap kesehatannya sehingga jika individu tersebut mengalami gangguan kesehatan maka ia akan segera mencari pelayanan kesehatan. Faktor lingkungan dapat menjadi salah satu faktor yang mendorong responden merasakan persepsi keseriusan sehingga termotivasi untuk memanfaatkan VCT (Purwaningsih, 2011). Ketika LSL berada di lingkungan orang yang memiliki pengetahuan dan pendidikan yang tinggi dan memiliki pengetahuan yang cukup tenantang VCT maka dapat mendorong responden yang berlatar belakang pendidikan rendah naumun tetap mau untuk menafaatkan layanan VCT. Persepsi keseriusan yang dirasakan terhadap HIV/AIDS berbeda pada masingmasing individu. Hal tersebut dikarenakan setiap orang memiliki pandangan yang subjektif terkait penyakit HIV/AIDS. 
Berdasarkan analisa data diketahui bahwa semakin rendah persepsi keseriusan seseorang terhadap HIV/AIDS, maka seseorang sedikit yang memanfaatkan layanan VCT untuk mengantisipasi penyakit HIV/AIDS. Banyak faktor yang tidak lepas dari persepsi keseriusan seperti modifying factor yaitu faktor demografi seseorang yang meliputi pendidikan dan lingkungan LSL.

\section{Hubungan perceived benefits dengan pemanfaatan VCT oleh LSL}

Berdasarkan Hasil uji statistik menunjukan bahwa tidak terdapat hubungan antara persepsi keuntungan dengan pemanfaatan VCT oleh LSL tahun 2020. Dengan kefisien krelasi rendah, responden yang memiliki persepsi keuntungan rendah maka mereka tidak melakukan pemanfaatan VCT.

Penelitian ini sejalan dengan sebuah penelitian Putu Krisna (2016) yang menyatakan bahwa tidak terdapat hubungan antara persepsi responden terhadap manfaat melakukan tes HIV dengan perilaku tes HIV. Penelitian ini tidak sejalan dengan penelitian prawesti (2018) yang menyatakan ada hubungan yang signifikan antara perceived benefit dengan pemanfaatan layanan VCT oleh LSL.

Peningkatan prevalensi HIV-AIDS yang semakin tinggi dikarenakan kurangnya kesadaran untuk memanfaatkan layanan VCT serta kurangnya pemahaman tentang HIV-AIDS dan VCT terutama bagi orang risiko tinggi. Banyak faktor yang dapat memengaruhi orang risiko tinggi untuk memanfaatkan VCT. Responden melakukan tes HIV karena dijangkau oleh penjangkau lapangan maupun diajak oleh teman, dalam proses penjangkauan, responden dijelaskan mengenai manfaat melakukan tes HIV (Putu Krisna, 2016). Faktor dukungan yang rendah dari orang sekitar dan media informasi juga ikut berpengaruh (Prawesti, 2018).

Dari penjelasan sebelumnya diketahui bahwa persepsi keuntungan yang rendah mayoritas tidak melakukan pemanfaatan VCT. Tantangan lebih besar dan berat karena kesadaran LSL yang masih tergolong rendah serta dukungan yang rendah dari orang sekitar dan media informasi. Perlunya menjangkau kelompok LSL yang masih terselubung untuk diintervensi agar mengakses layanan VCT serta mau merubah perilaku seksual yang tidak sehat.

\section{Hubungan perceived barrier dengan pemanfaatan layanan VCT oleh LSL}

Berdasarkan hasil uji statistik menunjukan bahwa terdapat hubungan antara persepsi individu dengan pemanfaatan layanan VCT oleh LSL tahun 2020. Hal ini dibuktikan dengan responden yang memiliki perceived barriers (persepsi hambatan) rendah mayoritas memanfaatkan layananan VCT. Sebaliknya, semakin tinggi perceived barriers LSL cenderung untuk tidak memanfaatkan layanan VCT.

Hasil penelitian ini berbeda dengan penelitian Malau (2015) yang menyatakan bahwa persepsi manfaat dan ancaman tidak memiliki pengaruh terhadap kejadian HIV-AIDS di klinik IMS dan VCT Veteran kota Medan. Penelitian 
ini sejalan dengan sebuah penelitian Prawesti (2018) yang menyatakan bahwa terdapat hubungan antara perceived barrier dengan pemanfaatan layanan VCT oleh LSL.

Menurut situmorang (2018) menyimpulkan bahwa ketakutan terhadap hasil tes yang positif kemungkinan merupakan salah satu faktor yang dapat menghambat pemanfaatan layanan. Ketakutan tersebut kemungkinan merupakan ketakutan terhadap kematian, takut atas nasib mereka sendiri atau takut karena harus menghadapi masalah yang lebih rumit di kemudian hari karena mendapat hasil tes yang positif. Ketakutan tersebut kemungkinan juga dapat diperburuk dengan adanya stigma atau diskriminasi yang akan diterima dari masyarakat atau pun keluarga.

Sehingga diketahui bahwa semakin tinggi hambatan seseorang dalam memanfaatkan layanan VCT maka akan semakin rendah keinginan seseorang untuk dapat memanfaatkan layanan VCT. hal tersebut tidak terlepas dari faktor lain yaitu ketakutan terhadap hasil tes yang positif dan adanya stigma atau diskriminasi.

\section{Hubungan cues to action dengan pemanfaatan layanan VCT oleh LSL}

Teori Health Belief Model Rosenstock (1982) dalam Ningrum (2016) menunjukkan bahwa perilaku juga dipengaruhi oleh isyarat untuk bertindak. Isyarat untuk bertindak adalah peristiwa-peristiwa, orang, atau hal-hal yang menggerakkan orang untuk mengubah perilaku mereka dalam melakukan tindakan terdapat factor pendorong untuk memutuskan menerima atau menolak tindakan tersebut. Isyarat internal yaitu isyarat untuk bertindak yang berasal dari dalam diri individu. Sedangkan isyarat eksternal yaitu isyarat untuk bertindak yang berasal dari interaksi intersosial, misalnya media massa, pesan, nasehat, anjuran atau konsultasi dengan petugas kesehatan.

Berdasarkan hasil uji statistik bahwa tidak terdapat hubungan antara cues to action dengan pemanfaatan layanan VCT oleh LSL di Kediri tahun 2020. Hal ini dibuktikan dengan responden yang memiliki cues to action (stimulus) tinggi mayoritas memanfaatkan layananan VCT. Sebaliknya, semakin rendah cues to action (stimulus) LSL cenderung untuk tidak memanfaatkan layanan VCT. Perilaku seseorang tergantung pada informasi yang diterima selama melakukan interaksi sosial secara terus menerus. Penelitian ini sejalan dengan sebuah penelitian Carmelita (2017) yang menyatakan bahwa tidak terdapat hubungan antara Alasan/Dorongan Untuk Bertindak dengan praktik Skrining IMS oleh LSL.

Menurut Prawesti (2018) Responden dengan stimulus yang tidak memanfaatkan layanan VCT karena faktor penghambat yang banyak seperti pekerjaan, jarak dengan akses puskesmas, dan didukung faktor persepsi manfaat yang rendah. Respoden memiliki persepsi manfaat yang rendah karena merasa VCT sangat menyita waktu sedangkan selain itu responden mengatakan saat 
mendapatkan penyuluhan, responden kurang begitu memahami maksud dari penyuluhan yang dilakukan oleh petugas puskesmas dan pengawas lapangan, hal tersebut dipengaruhi oleh tingkat pendidikan responden yang rendah sehingga merasa informasi yang diberikan kurang memiliki manfaat. Saat melakukan tindakan kesehatan terdapat faktor pencetus untuk memutuskan menerima atau menolak alternatif tindakan tersebut. Sehingga meskipun stmulus tinggi responden tetap tidak memanfaatkan layanan VCT karena didominasi oleh faktor penghambat.

Penyuluhan terkait VCT telah dilakukan petugas VCT dari puskesmas maupun petugas lapangan LSM, namun masih terdapat LSL yang belum memanfaatkan layanan VCT. Sehingga di ketahui bahwa cues to action (isyarat untuk bertindak) seseorang dipengaruhi oleh sumber informasi yang didapatkan LSL terkait HIV.

\section{KESIMPULAN}

Tidak ada hubungan antara Perceived susceptibility dengan pemanfaatan layanan klinik VCT oleh LSL, perceived seriousness dengan pemanfaatan layanan klinik VCT oleh LSL, perceived benefits dengan pemanfaatan layanan klinik VCT oleh LSL, cues to action dengan pemanfaatan layanan VCT oleh LSL, namun ada hubungan antara Perceived barrier dengan pemanfaatan layanan klinik VCT oleh LSL di Kediri

\section{SARAN}

Untuk terus menerus melakukan komunikasi, informasi, dan edukasi untuk meningkatkan pengetahuan LSL yang berisi informasi pencegahan peningkatan resik penularan HIV yang dapat meningkatkan persepsi LSL untuk datang dan memanfaatkan layanan VCT.

Kepada LSL agar memiliki perilaku seks yang baik dan aman dalam upaya pencegahan HIV, serta mampu memberikan informasi yang baik mengenai HIVAIDS dan VCT kepada LSL lainnya yang belum menjadi pengunjung, sehingga nantinya seluruh LSL di komunitas mau memanfaatkan layanan VCT.

Penelitian selanjutnya diharapkan hasil analisis ini dapat menjadi rujukan serta perlu di lakukan penelitian lebih lanjut terkait faktor yang berhubungan dengan pemanfatan klinik VCT pada LSL remaja dengan pendekatan teori Health Belief Model (HBM) guna meningkatkan kemauan untuk mendatangi klinik VCT

\section{DAFTAR PUSTAKA}

Arifin, Z. (2011). Acquired Immunodeficiency Syndrome (infeksi HIV/AIDS). Unair. Becker, M. H. (1974). The helath belief model and six role behavior, health education monographs winte.

Calles, N., Evans, D., and Terlonge, D. (2010). Pathophysiology of the Human Immunodeficiency Virus. HIV Curriculum for Health Professional. 
Carmelita, P. D. et al. (2017). Analisi faktor- faktor yang berhubungan dengan praktik skrining ims oleh lelaki seks lelaki (Isl) sebagai upaya pencegahan penularan hiv (study kasus pada semarang gaya comunnity). Journal Kesehatan Masyarakat (e-journal). Vol. 5, No. 3. Agustus 2017. pp 486-94.

Cipta.

Depkes. (2006). Modul pelatihan konseling dan tes suka rela hiv. Jakarta: Direktorat Jenderal Penyehatan Lingkungan.

Fatmala, R. D. (2016). Faktor predisposing, enabling dan reinforcing dalam pemanfaatan vct oleh laki-laki seks dengan laki-laki (Isl). Journal Berkala Epidemiologi, Vol. 4, No. 1 Januari 138-50.

Glanz, K. R. and B. K. Viswanath K. (2008). Health behavior and health education : Theory, research and practic. United States of America: Jossey-bass.

Glanz, K. R., Rimer B. K., and K, V. (2008). Health behavior and health education. America.

Gottwald, dan Brown. (2012). A guide to practical health promotion. UK: McGrawHill Education (UK).

Goverment of Weastern Australia. (2013). HIV/AIDS. Weastern Australia. Communicabel Disease Control Directorate Departemen of Health.

GWL-INA (2016). Buku kesehatan dan hak seksual serta reproduksi remaja gwl.

Hawari, D. (2009). Pendekatan psikoreligi pada homoseksual. Jakarta: Balai Penerbit FKUL.

Hayden, J. (2017). Introduction to health behavior theory. Unaited States of America: Library of Congress Cataloging -in Publication Data.

Hidayah A. S, Nurul et al. (2016). Self estem perilaku seksual berisiko pada remaja Isl (laki-laki seks laki-laki) (studi kualitatif di kabupaten jember). Artikeal ilmiah hasil penelitian mahasiswa, Universitas Jember

Jenderal Penyehatan Lingkungan.

Kemenkes RI. (2013). Pedoman nasional tes dan konseling hiv dan aids. Jakarta: Kementrian Kesehatan Republik Indonesi.

Kemenkes RI. (2017). Laporan perkembangan hiv-aids dan infeksi penyakit menular seksual (ims) triwulan I.

Kemenkes RI. (2019). Laporan perkembangan hiv aids dan penyakit infeksi menular seksual (PIMS) triwulan II tahun 2019. Jakarta: Direktorat Jenderal P2P.

Kementrian Kesehatan. 2011. Pedoman konseling dan tes HIV . Jakarta. Direktorat Komisi Nasional Penanggulangan AIDS. (2009). Situasi HIV dan AIDS di indonesia Lestari, H. E. P. (2016). Dukungan pasangan dengan niat yang melakukan hubungan seksual dengan laki-laki (Isl) untuk melakukan vct di kabupaten madiun. Journal Warta Bhakti Husada Mulia. Vol 3.

Notoatmodjo, S. (2012). Promosi kesehatan dan ilmu perilaku. Jakarta: Rineka Cipta Notoatmodjo, S. (2012). Promosi kesehatan dan ilmu perilaku. Jakarta: Rineka Cipta 
Notoatmodjo. (2007). Promosi kesehatan dan ilmu perilaku. Jakarta: PT. Rineka Notoatmodjo. (2012). Metode penelitian kesehatan. Jakarta: Rineka Cipta.

Nugroho, cahyo et al. (2018). Isyarat bertindak sebagai faktor pendorong lelaki seks lelaki dalam melakukan voluntary counseling and testing (vct). Journal Promosi Kesehatan indonesia. Vol. 13, No. 2, Agustus 2018.

Nugroho, Cahyo., Kusumaningrum, Tanjung Anita S. (2018). Isyarat bertindak sebagai faktor pendorong lelaki seks lelaki dalam melakukan voluntary counseling and testing. Vol. 13. No. 2.

Nursalam. (2015). Konsep dan penerapan metodologi penelitian ilmu keperawatan ; pedoman skripsi, tesis, dan instrumen penelitian keperawatan. Jakarta: Salemba Medika.

Nursalam. (2015). Metodologi penelitian ilmu keperawatan, edisi 4. Jakarta: Salemba Medika.

Omar, B. dan Gene, P. D. (2017). At Guide to AIDS. CRC press Taylor and Francis Group. NW.

Prawesti, Niken Ariska et al. (2018). Faktor pendorong pemanfatan layanan voluntary counseling and testing (VCT) oleh lelaki suka denagn lelaki (IsI) di Ism gaya nusantara. Jurnal Ners dan Kebidanan. Vol. 5, No. 2. Agustus 2018, pp. 129-36.

Purwaningsih, Misutarno, and Imamah, S. N. (2011). Analisis faktor pemanfaatan vct pada orang resiko tinggi hiv/aids.

Purwoastuti, endang. (2015). Panduan materi kesehatan reproduksi dan keluarga berencana. Yogyakarta: Pustaka baru press.

Sarwono. (2011). Psikologi remaja. Jakarta: PT. Rajka Grafindo.

Siahaan, Jokie MS. (2009). Perilaku menyimpang : Pendekatan sosiologi. Jakarta: PT Indeks

Sugiyono. (2010). Metode penelitian kuantitatif, kualitatif, dan r\&d. Bandung: CV Alfabeta.

Sugiyono. (2012). Metode penelitian kuantitatif, kualitatif, dan r\&d. Bandung: CV Alfabeta.

Sugiyono. (2013). Metode penelitian bisnis. Bandung: CV Alfabeta.

WHO. (2011). Scaling-up HIV services for men who have sex with men and transgender people [Online]. WHO. Available:http://www.who.int/mediacentre/news/releases/2011/hiv 2011062 1 /en/.

Yulrina, A., Novita, L., and Kiki, M. (2015). Bahan ajar aids pada asuhan kebidanan. Yogyakarta: Deeppublish Publisher. 